\title{
Nutrition Facts Analysis of Agung Banana Flour During Ripening
}

\author{
Yunita Rakhmawati ${ }^{1, *}$ Sri Rahayu Lestari ${ }^{1}$ Ade Wahyu Pratama ${ }^{1}$ Nur Sulistiyowati ${ }^{1}$ \\ ${ }^{1}$ Department of Biology, Faculty of Mathematics and Natural Sciences, Universitas Negeri Malang, Malang, East \\ Java, Indonesia \\ *Corresponding author. Email: yunita.rakhmawati.fmipa@um.ac.id
}

\begin{abstract}
Stunting is a condition that was lack of energy and protein for a long time. Tackling the problem of stunting is done by optimizing local food as a source of energy and nutrients. One of the local potentials that have not been widely utilized as an energy source is bananas. The aims of this study is knowing the nutritional composition of Agung banana flour based on post-harvest maturity levels. The results are the highest energy on the $5^{\text {th }}$ day of $5 \mathrm{kcal}$ and the protein content highest on day 1 was $2.76 \%$. Besides, the highest fat content is on the $5^{\text {th }}$ day at $0.59 \%$. In addition the highest carbohydrate content on the $2^{\text {nd }}$ day is $85.4 \%$.
\end{abstract}

Keywords: nutrition facts, agung banana flour, during ripening

\section{INTRODUCTION}

Stunting is a condition of body length or height that is not appropriate for his age. The condition is measured based on the value of $\mathrm{z}$-score TB / $\mathrm{U}<-2$ SD. [1]. Based on data from WHO as many as 151 million or $22.2 \%$ of toddlers suffer from stunting [2]. Meanwhile, data from Basic Health Research (Riskesdas) showed that as many as $30.8 \%$ of Indonesian children under five experienced stunting [3].

Stunting is a new issue that adversely affects nutritional problems in Indonesia because it affects the physical and functional of the child's body and increases the number of pains in children [1][4]. Stunting in toddlers needs to get special attention because it can cause inhibition of physical growth, mental development, and health status in children. In addition, stunting also leads to poor cognitive ability, low productivity, and increased risk of disease resulting in long-term losses to the Indonesian economy [5][18]. Stunting also increases the risk of obesity and obesity that can trigger metabolic syndrome diseases such as coronary heart disease, stroke, hypertension, and type 2 diabetes mellitus [6]. Tackling the problem of stunting is done by optimizing local food as a source of energy and nutrients. One of the local potentials that have not been widely utilized as an energy source is bananas.

Bananas are a fruit that is not affected by the seasons and is very young found in Indonesia. One of the bananas has a high enough starch content to potentially develop bananas as a source of energy [7]. The Agung banana is one of the horned banana cultivars (Musa paradisiaca) typical of Lumajang Regency. The utilization of Agung bananas is usually made in the form of banana chips as souvenirs typical of the region. However, its utilization in the form of banana horn flour has not been done much. The processing of Agung banana into the flour will be easier to modify into other kinds of processed [1].

Banana flour is widely used as a complementary food for breast milk (weaning food) for babies because it has a high carbohydrate content. Banana flour has a nutritional composition of $82.81 \%$ carbohydrates, $4.84 \%$ protein, and $1.07 \%$ fat [8]. The composition of these nutrients can change according to the level of ripeness of bananas post-harvest. Based on this background, the purpose of this study is to find out the nutritional composition of Agung banana flour based on postharvest ripening levels.

\section{METHOD}

This study was a descriptive study conducted from March-July 2021 at the Laboratory of Malang State University. Tools needed include ovens, basins, graters, scales, plastic sheaths. The ingredients needed include Agung bananas. Making Agung banana flour starts from bananas prepared with maturity levels from $\mathrm{H}+1$ to $\mathrm{H}+8$ days after harvest. Bananas were peeled then shredded 
roughly. Grate the banana in the oven at $60^{\circ} \mathrm{C}$ for 20 hours. Bananas that have been dried, blended, and sealed to get banana flour. Banana flour's nutritional composition have analyzed at the Laboratory of Agricultural Products Technology of Brawijaya University.

\section{RESULTS AND DISCUSSION}

The stage in the manufacture of Agung banana flour is a Agung banana that has been harvested, carried out the drying process for eight days after harvest, then mashed until it becomes flour and observations are made. In figure 1 is a majestic banana that is roughly shredded before being dried. While in table 1 is a picture of a reed banana dried and banana flour based on the day during ripening.

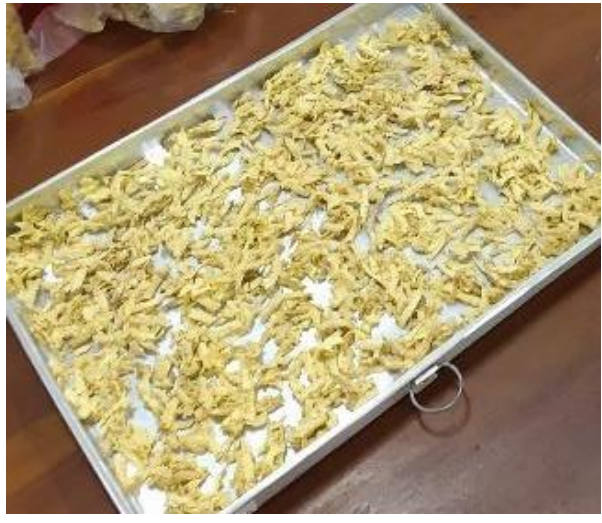

Figure 1. Agung banana before dried

Table 1. The Agung banana dried and Agung banana flour during the post-harvest ripening process

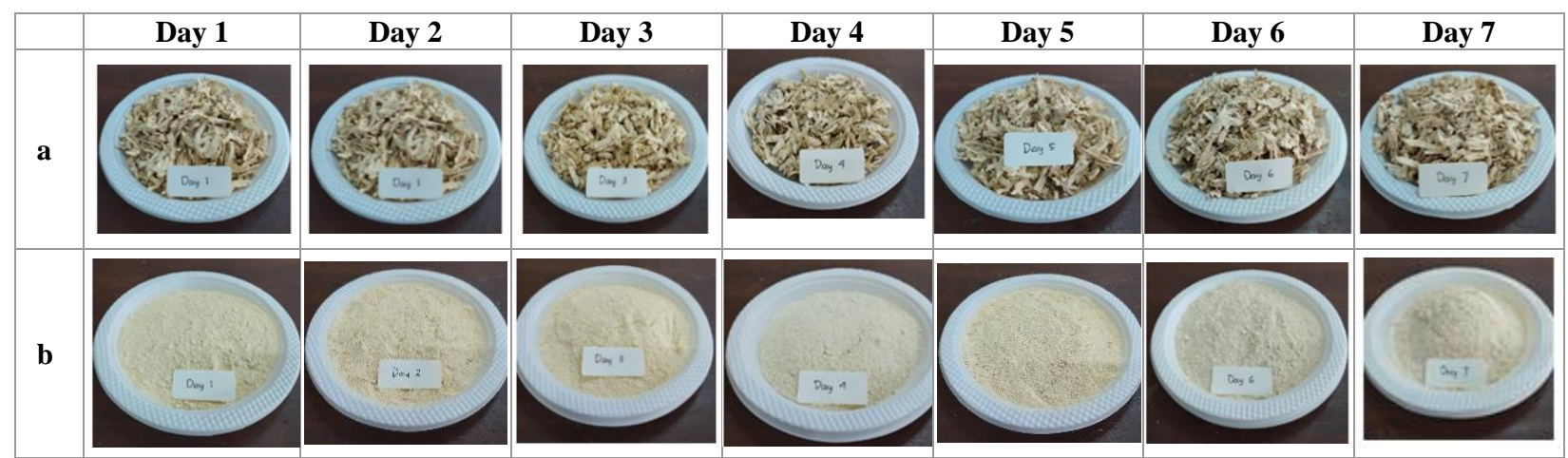

Table 2. The proxymate analysis of Agung banana flour during the post-harvest ripening process

\begin{tabular}{|c|c|c|c|c|c|}
\hline Day 1 & Wet Weight (gram) & Dry Weight (gram) & Flour Weight (gram) & \multicolumn{2}{|c|}{ Rate (\%) } \\
\cline { 3 - 5 } & & & & Water & Ash \\
\hline 1 & 340 & 130 & 130 & 10,59 & 1,98 \\
\hline 2 & 425 & 180 & 169 & 10,17 & 1,76 \\
\hline 3 & 400 & 161 & 154 & 10,64 & 1,85 \\
\hline 4 & 300 & 107 & 104 & 10,86 & 2,34 \\
\hline 5 & 320 & 116 & 109 & 11,06 & 2,15 \\
\hline 6 & 340 & 131 & 124 & 11,38 & 2,13 \\
\hline 7 & 340 & 125 & 116 & 11,49 & 2,26 \\
\hline 8 & 372 & 135 & 134 & 10,94 & 2,21 \\
\hline Average & 354,63 & 135,63 & 130,00 & 10,89 & 2,09 \\
\hline
\end{tabular}

Based on table 2 above, the Agung banana has a different wet weight ranging from 300 to 425 grams for eight days after harvest, with an average wet weight of about 354.63 grams. Agung bananas with a drying process for eight days after harvest have a different dry weight ranging from 107 to 180 grams with an average dry weight of about 135.63 grams. The average dry weight is $38 \%$ of the wet weight. The Agung banana has a different flour weight ranging from 104 to 169 grams for eight days after harvest, with an average flour weight of about 130.00 grams. The average wet weight difference with dry weight is about $38.04 \%$. In addition, the Agung banana has a water content for eight days after harvest that varies with the lowest water content on the second day of post-harvest around $10.17 \%$ and the highest water content on the seventh-day post-harvest around $11.49 \%$. The average water content of a Agung banana is about $10.89 \%$. The Agung banana has a different ash content for eight days post-harvest, with the lowest ash content on the second-day post-harvest around $1.76 \%$ and the highest ash content on the fourth day postharvest around $2.34 \%$. The average ash content of a Agung banana is about $2.09 \%$.

Based on the study results, the average dry weight of a Agung banana is $38 \%$ of the wet weight. The water content value of Agung banana flour during the eight days after harvest ranges from 10.17-11.49\%. According 
to Harefa \& Pato research (2017), the average water content of banana flour ranges from 2.42-9.64\% [11]. According to Palupi (2012), banana flour from the ambon banana type has the highest average water content of $14.75 \%$ and is a real difference $(p=0.05)$ from the type of kepok and horn banana [12]. The analysis of banana raw materials showed that the higher the level of ripeness of the fruit, the higher the water content contained in bananas. The exact drying time and temperature produce a higher water content in bananas that are cooked or ripe. On the other research, the higher the level of maturity, the ratio of fruit and skin meat will increase. The water content of fruit increases by respiration that breaks down starch into sugar and water. In addition, the migration of water from the skin into the fruit's flesh causes weight loss of the skin [13].

Measurement of ash levels aims to determine the amount of mineral content contained in the Agung banana flour. The Agung banana has a different ash content for eight days post-harvest, with the lowest ash content on the second-day post-harvest around $1.76 \%$ and the highest ash content on the fourth day post-harvest around $2.34 \%$. The average ash content of a Agung banana is about $2.09 \%$. In another study, the average value of ash levels ranged from 1.36 to $3.46 \%$. The higher fruit's ripeness level, the more ash content in the banana flour produced is increasing due to the increasing content of mineral salts in bananas formed along with bananas' ripening or ripening process. In general, bananas are nutritious fruits that contain minerals such as phosphorus, calcium, and iron [11]. According to Lolodatu et al. (2015), the high levels of ash in banana flour are a fruit rich in minerals such as potassium, magnesium, phosphorus, and iron [14]. Analysis of the composition of nutrients is carried out based on the level of maturity from the first day of harvest until the 8th day. The proximate analysis includes fat content, carbohydrate levels, and protein levels. In table 3 is a table of analysis of nutrients of banana flour in 100 grams of samples.

Based on the observations, table 3 shows the results of analysis of the nutrients of Agung banana flour in 100 grams of samples based on the level of maturity from the first day of harvest until the 8th day. The composition of nutrients analyzed included energy (cal), protein, fat, carbohydrates, and \% RDA based on a diet of $2150 \mathrm{cal}$. The average energy of banana flour produced is as much as $3.75 \%$, with the highest energy on the 5 th day of 5 Kcal. The highest protein content on day 1 was $2.76 \%$, with an average of $2.25 \%$. The highest fat content is on the 5 th day at $0.59 \%$, with an average of $0.42 \%$.

In comparison, the average carbohydrate content of $84.35 \%$, with the highest carbohydrate content on the 2 nd day is $85.4 \%$. Based on the \%RDA on the $2150 \mathrm{kcal}$ diet, the highest protein content is $5.11 \%$, with an average of $4.18 \%$. The average fat content $\mathrm{r} 0.59 \%$, and the highest content on the 5 th day is $0.82 \%$. Meanwhile, the highest carbohydrate content on the 2nd day was $26.52 \%$, and the average carbohydrate content was $26.19 \%$.

The proximate analysis includes water, ash, fat, carbohydrate, and protein levels. Based on the results of the study, the analysis of banana flour nutrients in 100 grams of samples included Agung banana flour has average energy produced of $3.75 \%$, protein levels with an average of $2.25 \%$, an average fat content of $0.42 \%$, and carbohydrate levels with an average of $84.35 \%$. Based on the $\%$ RDA on the $2150 \mathrm{kcal}$ diet, the protein content with an average of $4.18 \%$. The average fat content is $0.59 \%$, and the average carbohydrate content is $26.19 \%$. The results of the study, according to Campuzano et al. (2018), obtained the results of proxy analysis of Cavendish banana flour at various stages of ripening, expressed in $\mathrm{g} / 100 \mathrm{~g}$ of dry ingredients that are in stage 1 have an average fat content of $1.33(\mathrm{~g} / 1000 \mathrm{~g})$, the average protein content of $3.69(\mathrm{~g} / 1000 \mathrm{~g})$, the average carbohydrate content of 82.34 (g/ $1000 \mathrm{~g})$. Meanwhile, the 2nd stage has an average fat content of $1.38(\mathrm{~g} / 1000$ $\mathrm{g})$, the average protein content of $3.68(\mathrm{~g} / 1000 \mathrm{~g})$, an average carbohydrate content of 82.96 (g/ $1000 \mathrm{~g})$. [15]. According to Toledo et al. (2012), during the preclimacteric and climacteric stages, some protein enzymes are synthesized and involved in banana flavor, texture, defense, and ethylene synthesis [16].

Table 3. Table of analysis of banana flour nutrients in 100 grams of samples

\begin{tabular}{|c|c|c|c|c|c|c|c|}
\hline \multirow{2}{*}{ Day 1 } & \multirow{2}{*}{$\begin{array}{c}\text { Energy } \\
(\mathbf{c a l})\end{array}$} & \multirow{2}{*}{$\begin{array}{c}\text { Protein } \\
(\boldsymbol{\%})\end{array}$} & \multirow{2}{*}{ Fat $(\boldsymbol{\%})$} & \multirow{2}{*}{$\begin{array}{c}\text { Carbohydra } \\
\text { tes }(\boldsymbol{\%})\end{array}$} & $\begin{array}{c}\text { Protein } \\
(\boldsymbol{\%})\end{array}$ & Fat $(\boldsymbol{\%})$ & $\begin{array}{c}\text { Carbohydrates } \\
(\boldsymbol{\%})\end{array}$ \\
\hline 1 & 4 & 2,76 & 0,39 & 84,28 & 5,11 & 0,54 & 26,17 \\
\hline 2 & 4 & 2,25 & 0,42 & 85,4 & 4,17 & 0,58 & 26,52 \\
\hline 3 & 4 & 2,61 & 0,45 & 84,45 & 4,83 & 0,63 & 26,23 \\
\hline 4 & 3 & 2,24 & 0,35 & 84,21 & 4,15 & 0,49 & 26,15 \\
\hline 5 & 5 & 1,91 & 0,59 & 84,29 & 3,54 & 0,82 & 26,18 \\
\hline 6 & 4 & 1,92 & 0,48 & 84,09 & 3,56 & 0,67 & 26,11 \\
\hline 7 & 3 & 1,92 & 0,38 & 83,95 & 3,56 & 0,53 & 26,07 \\
\hline 8 & 3 & 2,42 & 0,32 & 84,11 & 4,48 & 0,44 & 26,12 \\
\hline $\begin{array}{c}\text { Average } \pm \\
\text { SD }\end{array}$ & $3.75 \pm 0.71$ & $2.25 \pm 0.33$ & $0.42 \pm 0.09$ & $84.35 \pm 0.45$ & $4.18 \pm 0.60$ & $0.59 \pm 0.12$ & $26.19 \pm 0.14$ \\
\hline
\end{tabular}

*\% AKG based on a $2150 \mathrm{kcal}$ diet 


\section{CONCLUSION}

The nutritional composition of Agung banana flour is based on the level of maturity during the eight days after harvest; among others, Agung banana flour has average energy produced, which is as much as $3.75 \%$, with the highest energy on the 5 th day of $5 \mathrm{kcal}$. The highest protein content on day 1 was $2.76 \%$, with an average of $2.25 \%$. The highest fat content is on the 5 th day at $0.59 \%$, with an average of $0.42 \%$. Meanwhile, the average carbohydrate content of $84.35 \%$, with the highest carbohydrate content on the 2 nd day is $85.4 \%$. Based on the \%RDA on the $2150 \mathrm{kcal}$ diet, the highest protein content is $5.11 \%$, with an average of $4.18 \%$. The average fat content is $0.59 \%$, and the highest is on the 5th day of $0.82 \%$. Moreover, the highest carbohydrate content is on the 2nd day, as much as $26.52 \%$, and the average carbohydrate content of $26.19 \%$.

\section{AUTHORS' CONTRIBUTIONS}

YR: concept the study, data collection, analysis, writing the manuscript, SRL, AWP, NS: data collection, analysis, writing the manuscript

\section{ACKNOWLEDGMENTS}

The authors would like to express gratitude to Universitas Negeri Malang for supporting this study.

\section{REFERENCES}

[1] F. Y. Adani and T. S. Nindya, "Differences in Energy Intake, Protein, Zinc, and Development in Stunting and Non-Stunting Toddlers," Amerta Nutr. ,vol.1, no.2, p. 46, 2017, doi: 10.20473/amnt.v1i2.6225.

[2] W.B. WHO, UNICEF \& Group, "Levels and Trends in Child Malnutrition," pp. 1-16, 2018.

[3] L. N. R. K. Basis, "Laporan_Nasional_ RKD2018_FINAL.pdf," Agency for Health Research and Development.p. 198, 2018, [Online]. Available:http://labdata.

litbang.kemkes.go.id/images/download/laporan/R KD/2018/Laporan_Nasional_RKD2018_FINAL.p df.

[4] S. Mugianti, A. Mulyadi, A. K. Anam, and Z. L. Najah, "Factors Causing Stunting Children Aged 25-60 Months in Sukorejo District of Blitar City," $J$. Ners and Midwifery (Journal Ners Midwifery),vol. 5, no. 3, pp. 268-278, 2018, doi: 10.26699/jnk.v5i3.art.p268-278.

[5] E. Setiawan, R. Machmud, and M. Masrul, "Factors Related to Stunting Events in Children Aged 24-59 Months in the Working Area of Andalas Health Center of Padang Timur District of Padang City in
2018," J. Kesehat. Andalas, vol. 7, no. 2, p. 275, 2018, doi: 10.25077/jka.v7.i2.p275-284.2018.

[6] World Health Organization, "Global Nutrition Targets 2025 to improve maternal, infant and young child," World Heal. Organs. , vol. 2, no. 6, pp. 375-388, 2018.

[7] D. N. Afifah, L. N. I. Sari, D. R. Sari, E. Probosari, H. S. Wijayanti, and G. Anjan, "Analysis of Nutritional Content, Resistant Starch, Glycemic Index, Glycemic Load and Receiving Power of Banana Flour Cookies Kepok (Musa paradisiaca) Enzymatic Thermodification and Green Bean Flour (Vigna radiata)," J. Apl. Technol. Pangan, vol. 9, no. 3, pp. 101-107, 2020.

[8] S. Ihromi, Y. Sulastri, and F. Arisandi, "Formulation of Banana Flour and Mocaf Flour Against Cake Quality," J. Agrotek UMMat,vol. 5, no. 2, p. 117, 2019, doi: 10.31764/agrotech.v5i2.702.

[9] R. D. Chandra, C. A. Siswanti, M. N. U. Prihastyanti, Heriyanto, L. Limantara, and T. H. P. Brotosudarmo, "Evaluating Provitamin A Carotenoids and Polar Metabolite Compositions during the Ripening Stages of the Agung Semeru Banana (Musa paradisiaca L. AAB)," Int. J. Food Sci. , vol. 2020, 2020, doi: 10.1155/2020/8503923.

[10] T. Happi Emaga, R. H. Andrianaivo, B. Wathelet, J. T. Tchango, and M. Paquot, "Effects of the stage of maturation and varieties on the chemical composition of banana and plantain peels," Food Chem. , vol. 103, no. 2, pp. 590-600, 2007, doi: 10.1016/j.foodchem.2006.09.006.

[11] W. Harefa and U. Pato, "Evaluation of Fruit Maturity Level on Quality of Banana Flour Produced," Jom Faperta,vol. 4, no. 2, pp. 1-12, 2017, [Online]. Available: https://media.neliti.com/media/publications/20348 9-evaluasi-tingkat-kematangan-buah-terhada.pdf.

[12] H. T. Palupi, "Effect of Piang Type and Soaking Ingredients On Characteristics of Banana Flour (Musa Spp) (Effect for Varieties of Matured Banana and Soaking Agent to Characterization of Banana Flour)," vol. 4, no. 1.

[13] A. Murtadha, E. Julianti, and I. Suhaidi, "The Effect of This Type of Ripening Drive on the Quality of Banana Goods (Musa paradisiaca L.) (Effect of Ripening Stimulant Types on Barangan Banana (Musa paradisiaca L.))," J. Food and Land Engineering. , vol. 1, no. 1, pp. 47-56, 2012.

[14] F. Lolodatu, E. S., Ekawati, L.M., \& Purwijantiningsih, "Quality of Non Flaky Chocolate Crackers With Variations in Substitution of Yellow Banana Flour," J. Technobiology,pp. 114, 2015. 
[15] A. Campuzano, C.M. Rosell, and F. Cornejo, "Physicochemical and nutritional characteristics of banana flour during ripening," Food Chem., vol. 256, no. February, pp. 11-17, 2018, doi: 10.1016/j.foodchem.2018.02.113.

[16] T. T. Toledo et al. , "Proteomic analysis of banana fruit reveals proteins that are differentially accumulated during ripening," Postharvest Biol. Technol. , vol. 70, pp. 51-58, 2012, doi: 10.1016/j.postharvbio.2012.04.005.
[17] W. Harefa, and U. Pato, "Evaluation of level fruit maturity to quality of banana Flour that produced", Jom FAPERTA Vol. 4 No. 2 October 2017

[18] Dwi Utami, A., Lanti, Y., \& Dewi, R. (2017). The Effect of Nutrient Intake and Socioeconomic Factor toward Stunting Incidence among Primary School Students in Surakarta. Journal of Epidemiology and PublichHealth, 2(1), 1-10. https://doi.org/jepublichealth. 